\title{
Development of a Model for Review Sharing in the Context of Mobile Phone Purchase Amongst Indian Millennials
}

\author{
Som Sekhar Bhattacharyya, National Institute of Industrial Engineering, India \\ (iD) https://orcid.org/0000-0003-3259-0319 \\ Sumi Jha, National Institute of Industrial Engineering, India \\ Shubham Khandelwal, National Institute of Industrial Engineering, India \\ Pulkit Jain, National Institute of Industrial Engineering, India \\ Anshul Ekka, National Institute of Industrial Engineering, India
}

\begin{abstract}
Online reviews provided important information towards affecting consumers' online shopping behavior. However, little research had been done in India how reviews influence young consumers' online buying behavior and review sharing. Millennials are experimental in nature and also are influenced by peers. The purpose of this research was to study the influence of online reviews on millennials' purchase behavior and study the characteristics. It was carried out in two phases in series (quantitative survey followed by qualitative interviews). The analysis was carried on primary data collected from a sample of 297 millennials with diverse backgrounds through an online survey. Factor analysis was then used in the first phase. Scale development was done to operationalize variables followed by structured equation modeling. A model on online customer reviews (OCR) sharing was developed. ANOVA was used for hypothesis testing. Qualitative findings arrived through content analysis. The research empirically attributed that reviews matter for individuals with distinguishing traits.
\end{abstract}

\section{KEYWORDS}

Indian Millennials, Mixed Methods, Model Development, Online Customer Reviews (OCR) Sharing, Scale Development

\section{INTRODUCTION}

The modern world market has been existing because of brick and click economies (Kuan, \& Bock, 2007). In the new millennium, click economy has become substantially potent in global market and online sales of goods and services has increasingly become omnipresent (Campo \& Breugelmans, 2015). The sales and marketing of goods and services online have opened up new avenues of customer feedback (Duan, Gu \& Whinston, 2008). Online Customer Reviews (OCR) entailed the product usage information voluntarily generated by internet users based on their personal experiences (Chen \& Xie 2007). The nature of reviews (good or bad) were dependent upon the satisfaction level of the users who had been wilfully shared their experiences and commented (Somohardjo,2017). In the past customer reviews were traditionally provided through information regarding product features or services to new 
customers (Court, 2009). This had a significant influence on purchase decisions (Holleschovsky et al, 2016; Wang et al, 2016; Chong et al, 2015). In this era of mobile handheld interconnected devices, consumers have been exposed to substantial information (Agarwal, 2014). Customers have increased the possibility to compare the products available in the market, unlike that in the past. (Agarwal, 2014) This presence of information (online reviews), had provided customers, the opportunity to shape their buying intention and attitude towards products in purchase consideration (Javadi \& Dolatabadi, 2012). Hence, customer reviews' analysis has become a factor to be reckoned for firm's marketing managers. This became a critical component in the new marketing communication mix. (Elwalda \& Lu, 2014). Firms had been paying keen attention for product development and service offerings through customer feedbacks since the reviews were being read by a substantial audience base (Brightlocal, 2018). Thus, this has over the years emerged as a crucial factor for marketing managers to address the concerns and queries to maintain firms' brand image (Chakraborty \& Bhat, 2017). Many successful brands had been using social media platforms for sustaining and interacting with customers (Wicks, 2015).

Online Customer Reviews (OCR) had allowed users to have at an individual level information processing confidence and capability with confidence (Ahsan,2017). This high level of confidence had been influencing their buying intention and attitude towards a product, service or a brand (Lee \& Ma, 2013). This has been specially so for the millennials. The reasons for the same were many. Younger population like (millennials), were believed to be more technology savvy and aware, as compared to their previous generations (like Gen X) (Smith, 2017). Millennials' also exhibited high mobility and connectivity behaviours of millennials (Ahluwalia, 2019). Past research had also indicated that millennials have been very well connected through digital means and social media (Aluwalia,2017). Further, it has been noted that millennials also seldom hesitated in sharing their good/bad product experiences in digital media (Medallia, 2016). Finally, millennials formed a substantial section of Indian population using and generating online reviews (Morgan Stanley, 2017). Thus, it had become important to understand their behaviour towards online reviews (Bhattacharyya, 2011). This behaviour entailed three elements namely, actively reading and using the inputs of OCRs, passively just reading online reviews and finally writing and sharing online reviews (Agarwal, 2014).

It would be important to note that the Indian economy registered growth in the first decade of twenty first century along with the increasing population of youth in India (Bhattacharyya, Rangarajan \& Vyas, 2012). This had made OCR analysis, very crucial for the firms in context to millennial customers in India (Raina, 2016). India was home to the largest millennial and Gen Z population scripting a promising consumer story. Millennial customers' in India were adopting technology in a vibrant manner (Verma, \& Bhattacharyya, 2016). As reported by a Boston Consulting Group study (Singhi, Sanghi, Jain, 2017), the disposable income of the middle-class population of India had also witnessed steep increase over the past few years. As reported by a Deloitte study (Talreja, Wahi, Ghosh, Marwah, \& Verma, 2018), Indian customers had registered an exponential increase in spending mainly in the electronics sector. The number of phones in usage outnumbered the size of the Indian population (Statista, 2019).

Online shopping had also witnessed a growth with major e-commerce players in India offering discount based online deals on products (Mallya \& Nair, 2016). Many companies had got into exclusive partnership with e-commerce websites for product launches and sales, for example, Xiaomi or One Plus4 with Flipkart or Amazon India, (Khullar, 2016). In these cases, the launch event was only through solicited invites (Stimac, 2014). These deals and privileges of enjoying the exclusivity had been successful in luring customers in substantial numbers to buy the products online (Toriello, Monica, 2019). Further, the option of free returns which were being offered by websites like Amazon, Flipkart and this further added icing on the cake for customers (Jordan, 2018). Such options provided customers the scope to try out new products and return the ones they disliked. In addition to this increased financial accessibility provided through credit cards, Equated/Equal Monthly Instalments options, had assisted in accelerating online purchases (Jain, Sanghi, \& Bawankule, 2018). Major 
smartphone manufacturers viewed Indian market as having big potential and decided to setup manufacturing facilities in India (Reuters, 2018). According to the research by International Data Corporation firm, quoted in recent India Brand Equity Foundation (IBEF) report (Indian Economy News, 2019) mobile shipments to India had increased by 14.5\% in year 2018 with shipments of 142.3 million units. India had over the years emerged as the second largest smartphone market in the world after China, and still mobile phone sales was registering growth (Indian Economy News, 2019).

This study focussed on mobile phone category. This was because it has been one of the highest products sold online. Further, mobile data package pricing in India has been one of the cheapest globally (Hariharan, 2019). This had led to an increase in online hours spent by Indian millennials and this had encouraged increased online shopping (Page, 2018). Mobile phones were also one of the most reviewed categories amongst the youths (Aluwalia,2017). The study focussed on how reviews mattered to young customers while making purchase decisions. The analysis had been carried out based upon a structured survey questionnaire followed by a semi-structural open-ended interview. The data was gathered from Indian millennials. The research objective was to develop a model for online review sharing in the context of mobile phone purchase amongst Indian millennials.

\section{LITERATURE REVIEW}

This section discussed the Literature Review (LR) study undertaken for the study. The authors for this research study had studied multiple journals listed in various journals databases like Jistor, EBSCO, Proquest and industry reports to gather insights on the relationship between OCR and buying behaviour of individuals. Further, the authors through LR study developed a conceptual model regarding the inclination and propensity of a millennial to undertake OCR sharing. The authors studied the articles for relevance and immediacy. Systematically, first the title, abstract and keywords of the articles were studied. For the articles which were relevant theoretically to the context of OCR a detailed study of the articles was followed. The LR study Table 1 has been presented in chronological order of the research output.

Based upon the systematic LR study, the authors found that there were multiple factors which affected consumers' buying preferences. It was found that friends, family members and reviews influenced consumer's buying decision (Lin \& Xu, 2017). However, customers' loyalty with brands, trust stood reduced the extent of effect of negative reviews and consumers still preferred to purchase and avail with their choice of brands neglecting the critical reviews (Lee \& Ma 2012). After referring the mentioned literature journal articles, the authors narrowed down to a set of variables which potentially might impact online purchase and OCR. The variables have been defined and presented in Table 2.

\section{RESEARCH GAP AND RESEARCH OBJECTIVES}

One could argue, that over the years the spending power of customers have increased, especially amongst the younger Indian population. Millennials were more interested in online purchasing. Millennials, played a crucial role in decision-making power not only for themselves but they also influenced individuals beyond their friends and families and even amongst different age groups through OCRs. Prior research works hadn't explicitly studied the behaviour of Indian millennials regarding OCRs. However, some research had been done to study the differences in choices with gender as a discriminating factor (Malar \& Thomson, 2016). Further, the effect of positive and negative reviews for the online purchase decision making was also studied (Hernandez-Ortega, 2019; Ullrich \& Brunner, 2015). However, a majority of the studies had been carried in the context of the United States, Europe and China, where the median age of the total population has been higher in contrast to that of India. Thus, the sample set taken for earlier studies didn't have the population mix similar to population mix of India. India is also socially a very different space (Bhattacharyya, 2012). A model on OCR sharing was also non-existent in the context of India. Further, the relationships between 
Table 1. Literature review on Online Customer Reviews (OCR)

\begin{tabular}{|c|c|c|c|}
\hline S. No & Author(s) & Methodology & Findings \\
\hline 1 & Park, Lee \& Han (2007) & $\begin{array}{l}2 \times 2 \times 2 \text { factorial design was used with three } \\
\text { independent variables review quality (high vs. low), } \\
\text { review quantity (few vs. moderate), and involvement } \\
\text { (high vs. low). }\end{array}$ & $\begin{array}{l}\text { Quality of online reviews was found to have a positive } \\
\text { effect on consumers' purchasing intention and } \\
\text { Low-involvement consumers were affected by the } \\
\text { quantity rather than the quality of reviews, unlike high } \\
\text { involvement customer. }\end{array}$ \\
\hline 2 & $\begin{array}{l}\text { Chintagunta, Gopinath \& } \\
\text { Venkataraman (2010) }\end{array}$ & $\begin{array}{l}\text { Data was collected from actual box office sales of } 148 \\
\text { movies during the period considered and analysed with } \\
\text { three complications that used national-level aggregate } \\
\text { box office data. }\end{array}$ & $\begin{array}{l}\text { Valence of the reviews was found to matter for box } \\
\text { office success unlike volume of reviews. }\end{array}$ \\
\hline 3 & Javadi \& Dolatabadi (2012) & $\begin{array}{l}\text { Regression analysis was used to establish relationship } \\
\text { between independent variables (various risks) and } \\
\text { dependent variables (attitude towards online shopping } \\
\text { behaviour). }\end{array}$ & $\begin{array}{l}\text { Online purchase was presented as complex socio- } \\
\text { technical phenomenon. Financial risk and non-delivery } \\
\text { risk had negative effect on attitude towards online } \\
\text { shopping behaviour. }\end{array}$ \\
\hline 4 & Shao (2012) & $\begin{array}{l}\text { Model was analysed using beta distribution. Mediation } \\
\text { analysis was carried out to consider the effect of initial } \\
\text { explanatory variable and mediating variables on the } \\
\text { dependent variable. }\end{array}$ & $\begin{array}{l}\text { Volume of the review was found to play a mediating } \\
\text { effect on the sales of a product. Further, controversial } \\
\text { reviews could arouse a discussion about product that } \\
\text { eventually translated into sales. }\end{array}$ \\
\hline 5 & Lee \& Ma (2012) & $\begin{array}{l}\text { Cross-validation approach to test and validate casual } \\
\text { model integrating research variables was used. } \\
\text { Descriptive analysis, correlation, t-test, exploratory } \\
\text { factor analysis, confirmatory factor analysis, and path } \\
\text { analysis were carried out. }\end{array}$ & $\begin{array}{l}\text { The authors explored how a consumer gained } \\
\text { confidence on buying after online reviews available via } \\
\text { their perceptions of both the benefits and costs of using } \\
\text { online consumer reviews. }\end{array}$ \\
\hline 6 & Elwalda \& Lu (2014) & $\begin{array}{l}\text { Impact of OCRs on trust and purchase intention was } \\
\text { studied. Structure equation modelling and linear } \\
\text { equation system were used for data analysis. }\end{array}$ & $\begin{array}{l}\text { OCR was presented as a critical component of new } \\
\text { marketing mix and an integrated framework, through } \\
\text { which OCRs' effected on purchase intention was } \\
\text { developed. }\end{array}$ \\
\hline 7 & $\begin{array}{l}\text { Wang,Wang, Xiaohang Zhang, } \\
\text { Mao and Wang (2015) }\end{array}$ & $\begin{array}{l}\text { The main effect and mediation effect were examined } \\
\text { through one-way ANOVA while the moderating effect } \\
\text { (interaction effect) by two-way ANOVA. }\end{array}$ & $\begin{array}{l}\text { Compared to mixed presentation, classified presentation } \\
\text { reduced purchase intention and increased purchase delay } \\
\text { due to the existence of loss avoidance. It confirmed } \\
\text { the interaction effect between online review sentiment } \\
\text { polarity and involvement. }\end{array}$ \\
\hline 8 & Ullrich \& Brunner (2015) & $\begin{array}{l}\text { Different response options towards a negative consumer } \\
\text { review were examined using a } 2 \text { × } 3 \text { × } 2 \text { factorial } \\
\text { between-subject design. Linear regression models were } \\
\text { used to analyse experimental data with product purchase } \\
\text { intention as the outcome variable. }\end{array}$ & $\begin{array}{l}\text { The effects of brand response, consumer response and } \\
\text { brand image on purchase intentions were compared after } \\
\text { a negative and a positive customer review. A negative } \\
\text { review more effectively effected purchase intention } \\
\text { than a positive review and a strong brand supported this } \\
\text { relationship. }\end{array}$ \\
\hline 9 & Malar \&Thomson (2016) & $\begin{array}{l}\text { Hypothesis were tested using independent sample T-test } \\
\text { and Chi-square test and stratified convenient sampling } \\
\text { was used for the collection of the data. }\end{array}$ & $\begin{array}{l}\text { Significant relationship between gender and the positive } \\
\text { product review was found. Also, ratings didn't had any } \\
\text { significant relationship with age of respondents and } \\
\text { customers considered positive reviews more than the } \\
\text { negative ones. }\end{array}$ \\
\hline 10 & $\begin{array}{l}\text { Phillips, Barnes, Krystin \& } \\
\text { Schegg (2016) }\end{array}$ & $\begin{array}{l}\text { Research model was tested using PLS-PM, equation } \\
\text { modelling technique with no distributional assumptions } \\
\text { for data samples. }\end{array}$ & $\begin{array}{l}\text { Reasons for OCRs becoming an important factor } \\
\text { in determining the business in hotel industry were } \\
\text { explored. It was found that OCRs had a mediating effect. }\end{array}$ \\
\hline 11 & $\begin{array}{l}\text { Chong, Li, Ngai, Ch’ng, \& } \\
\text { Lee (2016) }\end{array}$ & $\begin{array}{l}\text { Sentimental \& neural network analysis were used to } \\
\text { examine the datasets extracted from amazon.com pages } \\
\text { and the predictors of product sales were identified. }\end{array}$ & $\begin{array}{l}\text { How OCR, online promotional strategies and sentiments } \\
\text { from user reviews could help predict product sales was } \\
\text { explained. }\end{array}$ \\
\hline 12 & Ahsan (2017) & $\begin{array}{l}\text { OCRs were considered as consumer generated stories } \\
\text { and quantitative analysis approach was used on data of } \\
\text { number of units sold with ratings and reviews of the } \\
\text { products. }\end{array}$ & $\begin{array}{l}\text { The quantity of the review mattered. Also, some } \\
\text { negative reviews could increase the product visibility } \\
\text { and thus stimulated its purchase. }\end{array}$ \\
\hline 13 & Somohardjo (2017) & $\begin{array}{l}\text { Reviews were classified on basis of valance, recentness, } \\
\text { length with moderator variable of review type and a } 2 \times \\
2 \times 2 \times 2 \text { research design with } 16 \text { conditions were used. }\end{array}$ & $\begin{array}{l}\text { Impact of reviews on attitude and purchase intention } \\
\text { was higher when reviews were positive in comparison } \\
\text { with that when negative. The recentness and length of } \\
\text { reviews weren't significant. }\end{array}$ \\
\hline 14 & $\begin{array}{l}\text { Holleschovsky \& } \\
\text { Constantinides (2017) }\end{array}$ & $\begin{array}{l}\text { Data was analysed on two major aspects, measuring the } \\
\text { credibility characteristics and usability characteristics. }\end{array}$ & $\begin{array}{l}\text { Reviews were found to influence consumer purchasing } \\
\text { decisions only when consumers' reliance review was } \\
\text { high which was dependent on and influenced by format } \\
\text { characteristics of the review. }\end{array}$ \\
\hline 15 & Lin \& Xu (2017) & $\begin{array}{l}\text { A mock product-review web page was created for } \\
\text { research, each study condition was to manipulate review } \\
\text { valence and reviewer ethnicity. ANOVA \& ANCOVA } \\
\text { was used for testing the hypothesis. }\end{array}$ & $\begin{array}{l}\text { The authors demonstrated that review valence, reviewer } \\
\text { ethnicity and social distance each had a significant } \\
\text { effect on perceived reviewer trustworthiness, and review } \\
\text { valence had an influence on brand attitude and purchase } \\
\text { intention. }\end{array}$ \\
\hline 16 & Lee \& Choeh (2017) & $\begin{array}{l}\text { A classification-based review recommender using a } \\
\text { decision tree to identify and recommend reviews that } \\
\text { had a high level of helpfulness was proposed. }\end{array}$ & $\begin{array}{l}\text { Important determinants of helpfulness of online user } \\
\text { reviews from a pool of product, reviewer and textual } \\
\text { characteristics were suggested. }\end{array}$ \\
\hline 17 & Zhang, Xu, Zhao \& Yu (2018) & $\begin{array}{l}\text { Partial least squares method was employed to analyse } \\
\text { the data. A two-step procedure measurement model } \\
\text { and structural model were examined by convergent and } \\
\text { discriminant validity of the items. }\end{array}$ & $\begin{array}{l}\text { The relationship between impulsiveness to buy and } \\
\text { consumer perceived utilitarian and hedonic value were } \\
\text { explored. }\end{array}$ \\
\hline 18 & $\begin{array}{l}\text { Huang, Wang, Zhang \& Wang } \\
\text { (2018) }\end{array}$ & $\begin{array}{l}\text { Four analysis modules were used to quantify price, trust, } \\
\text { online reviews and integrating influences on purchasing } \\
\text { decisions to generate recommendations. }\end{array}$ & $\begin{array}{l}\text { A product recommendation model to improve the } \\
\text { recommendation performance of search engines was } \\
\text { proposed, this significantly improved the accuracy of } \\
\text { product recommendations. }\end{array}$ \\
\hline 19 & Chakraborty \& Bhat (2018) & $\begin{array}{l}\text { To examine the effects of online reviews on functional } \\
\text { and hedonic brand images structural equation modelling } \\
\text { technique was used. }\end{array}$ & $\begin{array}{l}\text { The authors investigated the effects of online reviews on } \\
\text { functional and hedonic brand images in the context of } \\
\text { consumer electronic products in India. }\end{array}$ \\
\hline 20 & Hernandez-Ortega (2019) & $\begin{array}{l}\text { Statistical confirmatory factorial analysis, mixed } \\
\text { between-within subject analysis of variance and post- } \\
\text { hoc analysis was used for the research. }\end{array}$ & $\begin{array}{l}\text { The effect of positive consumer reviews on individual's } \\
\text { satisfaction, brand attitude and purchase intention were } \\
\text { compared before and after consumption. OCRs had } \\
\text { asymmetrical effect for high and low performance. }\end{array}$ \\
\hline
\end{tabular}


Table 2. Variable definitions

\begin{tabular}{|l|l|l|}
\hline S. No & \multicolumn{1}{|c|}{ Variable } & \multicolumn{1}{c|}{ Definition } \\
\hline 1 & $\begin{array}{l}\text { Web Platform } \\
\text { Offerings (WPO) }\end{array}$ & $\begin{array}{l}\text { Web Platform Offerings (WPO) was the measure of the factors which help individuals } \\
\text { to choose one website platform over the other for carrying out online purchases. }\end{array}$ \\
\hline 2 & Peer Influence (PI) & $\begin{array}{l}\text { Peer Influence (PI) was the degree to which an individual's purchase decision is } \\
\text { affected by the perception or action of one's friends and family. }\end{array}$ \\
\hline 4 & $\begin{array}{l}\text { Social Status (SS) } \\
\text { Before Purchase } \\
\text { (CABP) }\end{array}$ & $\begin{array}{l}\text { Social Status (SS) was symbolic image that an individual garner by the purchase of a } \\
\text { product. }\end{array}$ \\
\hline 5 & $\begin{array}{l}\text { Brand Loyalty (BL) } \\
\text { such as product specification, features, best price and others prior to purchase. }\end{array}$ \\
\hline 6 & $\begin{array}{l}\text { Review Influence } \\
\text { (RI) }\end{array}$ & $\begin{array}{l}\text { Rrand Loyalty (BL) was the trust of a customer towards a particular brand that } \\
\text { influences a customer to purchase a brand without even considering critical reviews. }\end{array}$ \\
\hline 7 & $\begin{array}{l}\text { Critical Review } \\
\text { Analysis (CRA) }\end{array}$ & $\begin{array}{l}\text { Customer Review Analysis (CRA) was the level of details, customer seeks in review } \\
\text { characteristics like cumulative rating, recency of review and others to analyse the } \\
\text { reviews. }\end{array}$ \\
\hline 8 & $\begin{array}{l}\text { Review Sharing } \\
\text { (RS) }\end{array}$ & $\begin{array}{l}\text { Review Sharing (RS) was the intent of an individual to share different types of reviews } \\
\text { on online and offline platforms. }\end{array}$ \\
\hline
\end{tabular}

educational background, online reviews and buying attitude had not been explored yet for the Indian millennials in the context of mobile phone purchase. Previous research indicated that social factors had been playing a major role in consumer decision making (Lin \& Xu, 2017; Javadi \& Dolatabadi, 2012). OCRs have had a powerful interpersonal influence in buying attitude amongst consumers. The purpose of this study was to address the research gap by finding the role that OCRs, had played for the millennials in the context of buying a trending product like a mobile phone. Further, the study attempted to develop a model specifically on OCR sharing in the context of Indian millennials. The study also aimed to identify how educational background defined the way an individual engineered the buying decision regarding a technical product like a mobile phone.

Convenience has been considered to be USP for shopping online. The basic features/services offered by platforms such as (faster delivery, better user interface, multiple payment modes) assisted customers in hassle free shopping experience. Web Platform Offerings (WPO) helped customers to choose one platform over other. A phone model/brand being used by a friend/ family member influenced customer's purchasing decision and persuaded the customer in buying it. For certain customers, mobile phones had acted as a status of prestige hence, customers preferred buying the latest premium phones since they aspired to be the talk of the town. Customers carried out a critical comparison based on its offerings (features, specifications, prices) across multiple sites and even through offline store visits to be assured of their buying decision. Reviews influenced customers to switch brands or made them rethink their buying decision. Positive reviews resulted in boosting customer's confidence about their decision while negative/ critical reviews on the other hand created doubts in their mind to think more judiciously. While customers, did refer the reviews but the brand loyal customers preferred sticking to their brands despite the bad reviews for carrying out mobile purchase. Therefore, customers referring to reviews analysed reviews before finalizing their decision. The customers also engaged in review sharing at some instances. The extreme experiences (good as well as bad) were the instances where millennials customers cared to share their reviews more on social platforms. Given this background the authors based upon the literature review thus proposed a model on OCR sharing as depicted in Figure 1. 
Based upon the literature review conducted, the initial review sharing model proposed espoused relationship between all variables. Thus, the initial proposed model on OCR sharing, relationship between the variables were established. WPO, PI and BL had relationship with online shopping frequency and the average ticket size for customers. SS and RI had relationships with both online and offline shopping frequency. Average ticket (AT) size and frequency of online purchase was found to have relationship with review sharing. Critical analysis before purchase (CABP) was proposed to be a major factor influencing platform selection (online or offline). Frequency of online purchase would be related to Review Sharing (RS) as, customers with high frequency would have higher inclination towards sharing reviews on online platforms. A customer who associated one's purchase with social status would have a higher average ticket size. Thus, it might be attributed that there could be relationship between Social Status (SS) and Average Ticket Size (AT). The authors thus formulated hypothesis, anticipating strong relations between the earlier defined variables for carrying out online purchase. The following hypothesis were proposed to be tested:

$\mathbf{H}_{1}$ : Web Platform Offering (WPO) is positively related to the frequency of the online purchase.

$\mathbf{H}_{2}$ : Brand Loyalty (BL) is positively related to the frequency of online purchase.

$\mathbf{H}_{3}$ : Review Sharing (RS) is positively related to Average Ticket Size (AT).

$\mathbf{H}_{4}$ : Frequency of online purchase is positively related to Review Sharing (RS).

$\mathbf{H}_{5}$ : Peer Influence (PI) is positively related to frequency of online purchase.

$\mathbf{H}_{6}$ : Purchase exposure (PE) is positively related to review sharing (RS).

$\mathbf{H}_{7}$ : Social status (SS) is positively related to the average ticket size (AT).

$\mathbf{H}_{\mathbf{8}}$ : Critical Analysis Before Purchase (CABP) is positively related to frequency of online purchase.

$\mathbf{H}_{\mathbf{9}}$ : Web Platform Offerings (WPO) and Peer Influence (PI) are positively related.

$\mathbf{H}_{10}$ : Critical Analysis Before Purchase (CABP) is negatively related to Brand Loyalty (BL).

$\mathbf{H}_{11}$ : Review Influence (RI) is positively related to Average Ticket Size (AT).

$\mathbf{H}_{12}$ : Critical Analysis Before Purchase (CABP) is positively related to Average Ticket Size (AT).

$\mathbf{H}_{13}$ : Purchase behaviour varies significantly with the education stream.

$\mathbf{H}_{14}$ : Purchase behaviour varies significantly with location.

$\mathbf{H}_{15}$ : Purchase behaviour varies significantly with gender.

Figure 1. Proposed model on review sharing

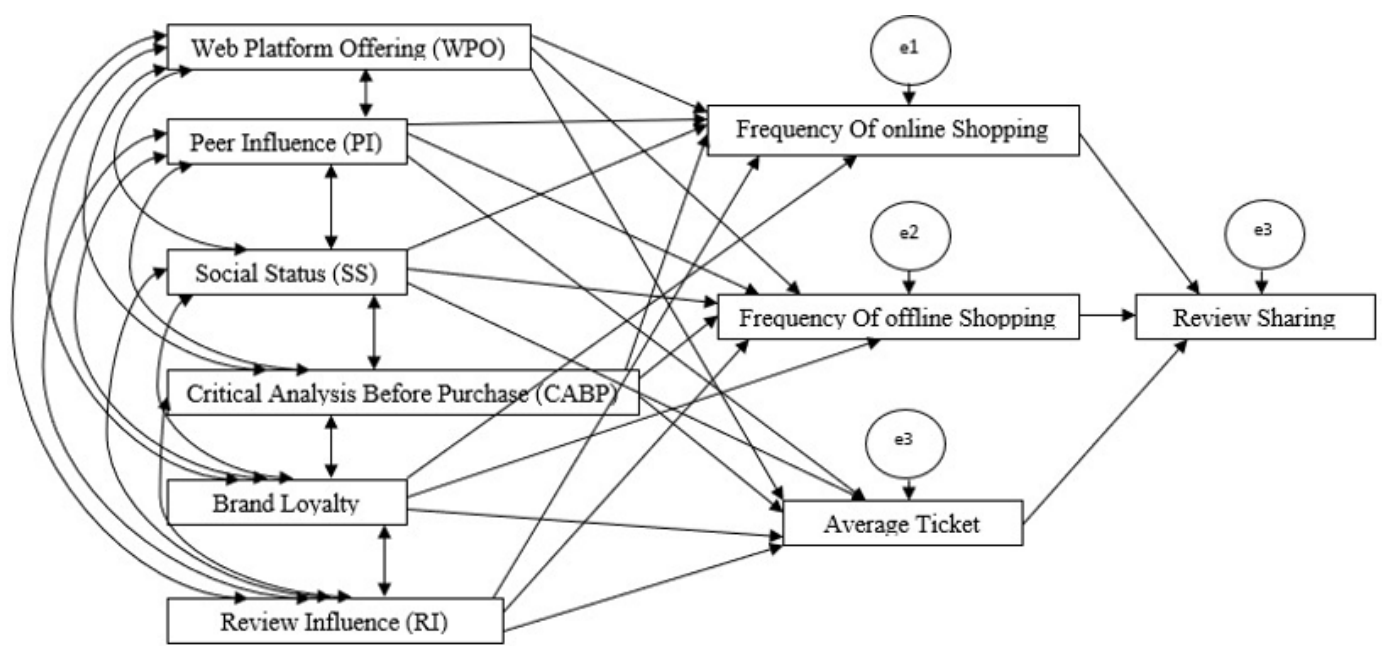




\section{RESEARCH METHODOLOGY}

The research was aimed towards development of a model on OCR sharing. The research was carried out as a mixed method study in two phases quantitative followed by qualitative (Creswell \& Clark, 2017). The dominant and first stage was quantitative, while the second stage was qualitative used for triangulation purposes (Creswell \& Clark, 2017):

Quant $\rightarrow$ Qual

\subsection{Phase I: Quantitative Phase}

Phase I of the study, started with data collection through online questionnaire with Indian millennials as the target population. The items of the questionnaire were developed from the literature, after screening and redefinition against the online research. However, the scales were not adopted or adapted. Non-probabilistic convenient sampling technique was used for the collection of data. Firstly, the data obtained was cleaned, and factor analysis was performed to identify the variables. All the analysis was performed using IBM SPSS statistics version 25 software package. Principal component analysis method of factor extraction was used with varimax rotation and the loadings less than 0.4 were supressed. For scale development (that aimed to operationalise the variables) Cronbach alpha and factor analysis was employed. After the identification of the factors and scale development, Structured Equation Modelling (SEM) was performed. SEM was used to test the model validity and the casual relationships among the variables. First, the relationships between the variables were examined to ensure the validity of the constructs. Then path analysis was performed in which the hypothesised relationships among variables were tested. ANOVA was then performed for hypothesis testing. It was used to identify if the purchase behaviour among the millennials differed with different education background (engineering -non-engineering), location (tier I -tier II city) and gender.

\subsection{Phase II: Qualitative Phase}

As a part of triangulation, subsequent to the findings from phase-I (quantitative study) a qualitative study was carried out. Thematic content analysis was carried out to ascertain the presence or absence of themes emergent from phase-I.

\subsection{Data Collection}

This section discussed the phase wise data collection process. In phase I, that was quantitative phase, the authors formulated a questionnaire in google form format to study the impact of online consumer reviews on buying behaviour of young population. This has been commonly used in past studies. The questionnaire was divided into three parts. The first part focussed on checking for young customer's reasons for buying from a certain website. The second part had questions to assess the helpfulness of OCR and how it affected buying decision. The third part covered the demographics of the respondents. There were 37 items in the questionnaire which were rated in a five-points Likert scale (1 to 5). Non probabilistic convenient sampling had been used by circulating the google form online among different college students in India through social media (personal messages). The data collection was carried out in the month of January to March,2019 where a total of 297 responses had been collected out of which 30 responses which were incompletely filled were discarded. The majority of respondents were aged 20-22 years studying in different educational streams. The sample size of 296 was justifiable because the authors met the criteria of item sample ratio of more than 1:5 (Cattell, 1978; Gorsuch, 1983). The communality values were also above 0.5 for all the variable. The effect of sample size decreased as the communality values were above 0.50 (MacCallum, Widaman, Zhang and Hong, 1999). There were two educational streams considered, engineering and non-engineering. The summary of the collected has been tabulated in Table 3 . 
Table 3. Phase -1 Data sampling

\begin{tabular}{|c|c|c|c|}
\hline Demography & Average & Minimum & Maximum \\
\hline Age (years) & 22.5 & 16 & 32 \\
\hline Number of siblings & 1.24 & 0 & 33 \\
\hline $\begin{array}{c}\text { Number of close } \\
\text { friends }\end{array}$ & 5.33 & 0 & 70000 \\
\hline Monthly pocket money (INR) & 8000 & Female (101 repondents,37.96\%) \\
\hline Gender & $\begin{array}{c}\text { Males (165 } \\
\text { repondents,62.03\%) } \\
\text { Tier I city (124 } \\
\text { repondents,46.61\%) }\end{array}$ & Tier II city (142 repondents,53.38\%) \\
\hline Location & $\begin{array}{c}\text { Engineer }(113 \\
\text { repondents,42.48\%) }\end{array}$ & Non-engineer (153 repondents,57.51\%) \\
\hline Education Stream & & \\
\hline
\end{tabular}

In phase II, that was qualitative phase, the data collection was carried out through telephonic interviews of target population. The subject of this study phase were six respondents having the following traits; male \& female, aged between 20-22 years, coming from different educational backgrounds (engineering, non-engineering) from different (tier) cities in India. Telephonic interviews were conducted with the respondents to understand their responses to the following questions:

Q1: When you purchased a mobile phone, what were the factors that you considered and why these factors?

Q2: How online reviews influenced your purchase decision?

Q3: What was the nature of influence of your friends and families towards the purchase of a mobile phone?

Q4: What are your views regarding writing online reviews?

The answer to these questions were used as a corroboration both for data as well as method triangulation (Creswell \& Clark, 2017).

\section{RESULTS AND DISCUSSION}

The findings of the phase-I and phase-II have been presented in this section. For phase I, that was quantitative phase, the data was collected on a five-point Likert scale. Out of total 297 responses, 30 responses (poorly filled) were dropped. Factor analysis was performed on the dataset for dimension reduction and identification of the variables. KMO and Bartlett's test was used to test for sample adequacy to perform factor analysis. The KMO measure thus obtained was 0.862 which was greater than 0.6 (threshold value) (Cerny, \& Kaiser,1977) and Bartlett's test (Arsham,2011) for sphericity was also found to significant which suggested that the responses were adequate to perform factor analysis. Principal component method of extraction was used for factor analysis with varimax rotation and the loadings having a value lesser than 0.4 were supressed (Muller, 1978). The variables, number of items, their $\alpha$ reliability coefficient (Churchill 1979), and percentage of total variance explained has been tabulated in Table 4 . A score of more than 0.5 was acceptable to ensure the item's reliability. (Nunnally,1978).

Four items were dropped from the list of variables either because of high cross loading (more than 0.4) or because of poor reliability coefficient (alpha) value. Factor Peer Influence had only two items as was retained as suggested by Jensen, et al., (2003) and Wanous et al., (1997). These 
Table 4. Scale development value of variables

\begin{tabular}{|c|c|c|c|c|}
\hline S.no & Variable & $\begin{array}{c}\text { Number of } \\
\text { Items }\end{array}$ & Alpha( $\boldsymbol{\alpha})$ & \% Variance \\
\hline 1 & Preference for website (POW) & 5 & 0.662 & 49.936 \\
\hline 2 & Peer influence (PI) & 2 & 0.942 & 94.563 \\
\hline 3 & Social Status (SS) & 4 & 0.815 & 64.544 \\
\hline 4 & Critical analysis before purchase & 5 & 0.781 & 53.722 \\
\hline 5 & Brand loyalty (BL) & 3 & 0.859 & 78.038 \\
\hline 6 & Review influence (RI) & 5 & 0.757 & 50.966 \\
\hline 7 & Critical review analysis (CRA) & 5 & 0.809 & 57.650 \\
\hline 8 & Review Sharing (RS) & 5 & 0.815 & 57.551 \\
\hline
\end{tabular}

were items specifically for factor peer influence and had very high loading. After factor analysis, Confirmatory factor analysis (CFA) was performed. The goodness of fit indices was presented in Table 5. Confirmatory factor analysis for all the variables were conducted to examine whether the construct of variables under study are distinct from each other or not. Table 5 indicated the results of the measurement model. The eight-factor measurement model (M1) was found to be of good fit with the data; $\chi^{2}=167.3, \mathrm{df}=98, \mathrm{CFI}=0.97, \mathrm{GFI}=0.93, \mathrm{TLI}=0.93, \mathrm{RMR}=0.04$ and $\mathrm{RMSEA}=0.05$. All parameters had significant factor loadings $(\mathrm{p}<0.01)$. This confirmed the convergent validity of the measurement model. The discriminant validity of the measurement model was tested by merging all variables as the one-factor model (M8). The model showed poor fit; $\chi^{2}=341.3, \mathrm{df}=99, \mathrm{CFI}=0.59$, $\mathrm{GFI}=0.60, \mathrm{TLI}=0.60, \mathrm{RMR}=0.14$ and $\mathrm{RMSEA}=0.23$. For Model 2- the seven variables were merged, and CFA was conducted to test different factor structure. The best fit model was, model 1 with eight distinct factors.

The final operational definitions of the variables are presented in Table 6.

Model testing considering the variables was done using AMOS and its results have been presented in Table 7 the final model on OCR has been depicted in Figure 2.

One needed to note that $\mathrm{P}$ was the proposed model while $\mathrm{F}$ represented the final model. The CMIN/DF value for the proposed model (20.306) was too high, value of CMIN less than 5 was

Table 5. Goodness of fit indexes

\begin{tabular}{|c|c|c|c|c|c|c|c|}
\hline & $\boldsymbol{\chi}^{\mathbf{2}}$ & Df & GFI & CFI & TLI & RMR & RMSEA \\
\hline Model 1 & 1670.3 & 98 & 0.93 & 0.97 & 0.93 & 0.04 & 0.05 \\
\hline Model 2 & 213.1 & 99 & 0.81 & 0.78 & 0.73 & 0.06 & 0.10 \\
\hline Model 3 & 272.32 & 99 & 0.80 & 0.70 & 0.73 & 0.08 & 0.15 \\
\hline Model 4 & 251.1 & 99 & 0.77 & 0.67 & 0.65 & 0.11 & 0.18 \\
\hline Model 5 & 324.8 & 99 & 0.68 & 0.63 & 0.62 & 0.11 & 0.20 \\
\hline Model 6 & 337.9 & 99 & 0.63 & 0.61 & 0.61 & 0.13 & 0.22 \\
\hline Model 7 & 340.1 & 99 & 0.62 & 0.60 & 0.60 & 0.13 & 0.22 \\
\hline Model 8 & 341.3 & 99 & 0.60 & 0.59 & 0.60 & 0.14 & 0.23 \\
\hline
\end{tabular}

$\mathrm{GFI}=$ Goodness of fit index, $\mathrm{CFI}=$ Comparative fit index, $\mathrm{TLI}=$ Tucker Lewis fit index, $\mathrm{RMR}=$ Root mean square residual, RMSEA= Root mean square error of approximation 
Table 6. Variable operationalization

\begin{tabular}{|c|c|}
\hline Variables & Items \\
\hline $\begin{array}{l}\text { Web } \\
\text { Platform } \\
\text { Offerings } \\
\text { (WPO) }\end{array}$ & $\begin{array}{l}\text { Customer would prefer buying from a particular website based on } \\
\text { - Ease of user interface } \\
\text { - Speed of delivery } \\
\text { - Delivery charges } \\
\text { - Offered modes of payment (wallets/UPI/COD/EMI) } \\
\text { - Return policy }\end{array}$ \\
\hline $\begin{array}{l}\text { Peer } \\
\text { Influence } \\
\text { (PI) }\end{array}$ & $\begin{array}{l}\text { Being influenced by a person whom the individual admires, customer would prefer to buy a particular } \\
\text { - Brand of mobile phone } \\
\text { - Mobile phone model }\end{array}$ \\
\hline $\begin{array}{l}\text { Social } \\
\text { Status (SS) }\end{array}$ & $\begin{array}{l}\text { Customer would buy a particular mobile phone because the individual } \\
\text { - Siblings or friends do not have it } \\
\text { - Desires to be a talk of the town / lime light amongst friends } \\
\text { - Considers phone as his status symbol } \\
\text { - Discerns it as from a superior country, because the country of origin matters to the customer }\end{array}$ \\
\hline $\begin{array}{l}\text { Critical } \\
\text { Analysis } \\
\text { Before } \\
\text { Purchase } \\
\text { (CABP) }\end{array}$ & $\begin{array}{l}\text { Customer would decide the phone purchase based on } \\
\text { - Specific features desired such as camera, screen size, battery, etc. } \\
\text { - The critical evaluation done on the website from where the individual desired to buy } \\
\text { - Critical comparisons across multiple websites } \\
\text { - Offline experience with phone, because of visiting a physical store or from someone who owned } \\
\text { - Conclusions made after reading online reviews }\end{array}$ \\
\hline $\begin{array}{l}\text { Brand } \\
\text { Loyalty } \\
\text { (BL) }\end{array}$ & $\begin{array}{l}\text { Customer would buy a phone } \\
\text { - If the brand is trustworthy } \\
\text { - From a trusted brand, even ignoring the bad reviews } \\
\text { - Without looking at reviews because one or more of the family/friends' members had been using it } \\
\text { and recommended its purchase }\end{array}$ \\
\hline $\begin{array}{l}\text { Review } \\
\text { Influence } \\
\text { (RI) }\end{array}$ & $\begin{array}{l}\text { Customer would } \\
\text { - Switch brands based on review ratings } \\
\text { - Read ratings and reviews of products for every online electronic purchase } \\
\text { - Read positive and favourable (4 \& } 5 \text { star) reviews first } \\
\text { - Read negative but critical ( } 1 \text { \& } 2 \text { star) reviews first } \\
\text { - Consider online reviews for offline electronic purchases as well }\end{array}$ \\
\hline $\begin{array}{l}\text { Critical } \\
\text { Review } \\
\text { Analysis } \\
\text { (CRA) }\end{array}$ & $\begin{array}{l}\text { Customer would look for } \\
\text { - The number of individuals who provided reviews } \\
\text { - Cumulative ratings while considering ratings of electronic products } \\
\text { - The cause of complain about reviews which were complaining in nature } \\
\text { - Following up with customer service over email/chat/telephonic communication, if reviews were } \\
\text { confusing } \\
\text { - Recency of the reviews }\end{array}$ \\
\hline $\begin{array}{l}\text { Review } \\
\text { Sharing } \\
\text { (RS) }\end{array}$ & $\begin{array}{l}\text { Customer would write } \\
\text { - Positive reviews only } \\
\text { - Negative reviews only } \\
\text { - Critical reviews only } \\
\text { Customer did not write reviews, } \\
\text { - For electronic purchases } \\
\text { - But still recommended individuals to refer to it while carrying out purchase }\end{array}$ \\
\hline
\end{tabular}

considered to be good for a model. The CMIN/DF was 4.723 which was acceptable and hence using CMIN/DF as parameter the final model was better model than the initially proposed model. The GFI and AGFI value should be greater than 0.9 for model to be good. The GFI values for initial model and final model were 0.906 and 0.911 both of which could be considered good. The adjusted goodness of fit value (AGFI) for proposed model was 0.427 on the other hand the same for the final 
Table 7. Model fitting values

\begin{tabular}{|c|c|c|c|c|c|c|c|c|}
\hline Model & CMIN & DF & CMIN/DF & RMR & GFI & AGFI & PGFI & RMSEA \\
\hline Default (P) & 182.76 & 9 & 20.306 & 1.984 & 0.906 & 0.427 & 0.148 & 0.27 \\
\hline Independence(P) & 588.2 & 45 & 13.071 & 2.775 & 0.633 & 0.552 & 0.518 & 0.213 \\
\hline Default (F) & 14.169 & 3 & 4.723 & 1.849 & 0.911 & 0.896 & 0.662 & 0.073 \\
\hline Independence(F) & 202.68 & 10 & 20.268 & 1.992 & 0.791 & 0.686 & 0.527 & 0.27 \\
\hline \\
RMR- Root mean square residual, GFI- Goodness of fit index, AGFI -Adjusted goodness of fit index \\
PGFI- Parsimonious goodness of fit index, RMSEA- Root mean square error of approximation \\
\hline
\end{tabular}

model was 0.896 which was considerably better. Hence, using AGFI criteria final model was better than the initially proposed model. For model to be good the root mean square error of approximation (RMSEA) should be less than 0.08. The RMSEA value for in initial proposed model (0.27) was very large whereas the RMSEA value for the final model (0.073) was less than 0.08, suggesting that the final model was better. On comparative analysis of the model fitting values it was found that the final model was better than the initially proposed model on all model fitting parameters. Thus, the initial proposed model was dropped, and the final model was selected.

As per the final model on OCR sharing, Web platform offering (WPO) had a positive relationship with the frequency of online purchase. This suggested that the customers who considered factors such as the payment options availability, delivery speed, return policy and such others made customer shop online and serve as a determinant of the web platform, selected online purchase mode more often. This was similar as found in study (Dave,2017). The final model suggested that PI had lesser level of significance with frequency of online purchase for mobiles. SS had weak relationship in the model. It could be attributed that as majority of target population were students, social status was not common among them. The customers who critically analysed before undertaking purchase, liked to

Figure 2. Final model on review sharing

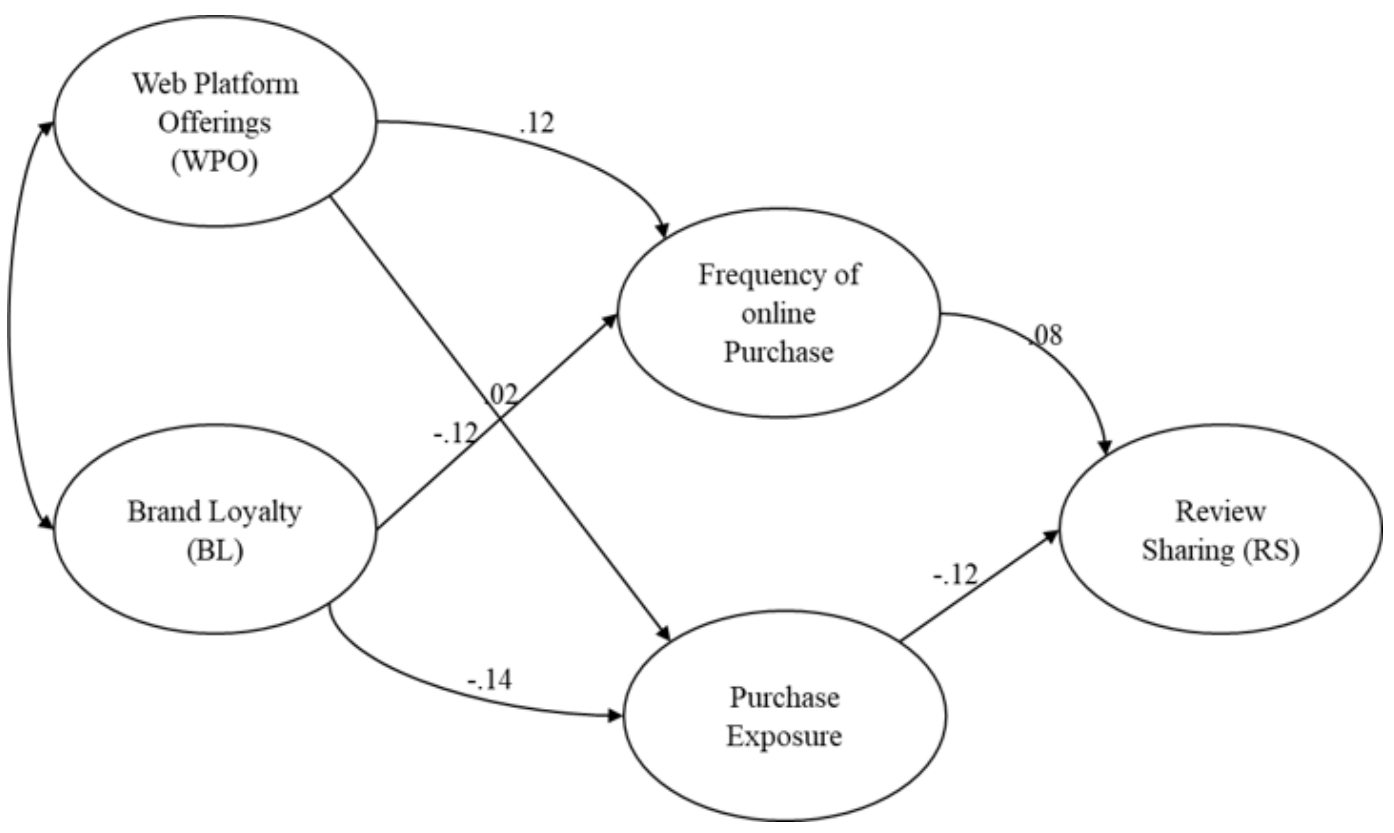


physically investigate the product before purchase, rather than waiting for the product to get delivered and then experiencing the same. This might be a reason for weak relationship between CABP and online purchase frequency as reported in this study.

This study indicated that brand loyalty had significant relationship with frequency of purchase and with purchase exposure. This suggested that brand loyal customer wasn't necessarily the frequent buyer on online platforms. This was in line with the research conducted on customer loyalty online versus offline (Dahaher, 2003) and other aspects of digital adoption (Verma, Chaurasia \& Bhattacharyya, 2019). This might be attributed to the fact that brand loyal customers updated their mobile phone less frequently as per the new launches of their particular brands of choice. For instance, a user using a generation $\mathrm{X}$ phone might consider upgrading the phone only when generation $\mathrm{X} \mathrm{P}+1$ was being launched. Additionally, brand loyal customers one could argue would prefer to purchase from brand exclusive stores rather than purchasing items online. As per the model, there was no significant relationship between frequency of online purchase and RI. The attributed reason could be that, reviews couldn't trigger a purchase from scratch for a millennial customer. The desire for new phone couldn't be created from zilch through OCR. However, choosing a different brand/model could be influenced by reviews. It was found that customers referred to multiple websites for carrying out critical analysis by checking for recency of reviews, comparing products features and pricings. Customers were engaged in review sharing at some instances. The extreme experiences (good as well as bad) were the instances where millennials customers cared to share their reviews in a more pronounced manner. Often, customer were unbiased towards the type of reviews they read. This was unlike the findings of previous research, which suggested positive reviews had greater impact on online purchase behaviour (Somohardjo, 2017). As per the model, variables such as PI, SS, CABP and CRA tended to have a lesser impact on millennials for carrying out their online purchases. This could be because of the fact that, millennials possessed good knowledge about phones and were well aware about its specifications and they referred online reviews to reconfirm their decisions. SS didn't have had a significant relationship with online purchase as per the model. It could be attributed that majority of the target population of the study belonged to the student category for whom value for money was a top priority. The purchase exposure was taken as the multiplication of frequency of the online purchase times the average ticket size of the purchase. Though WPO had significant relationship with the frequency of the online purchase, yet it didn't affect the purchase exposure. The ANOVA results output for frequency of online $\&$ offline shopping, average ticket size and purchase exposure with location, education stream and gender as independent variables have been tabulated in Table 8, Table 9 and Table 10 respectively.

The ANOVA result demonstrated in Table 8 that, there was significant difference between Indian tier I and tier II city millennials customers when it involved the frequency of online purchase, frequency of offline purchase and purchase exposure. The study results indicated that the frequency of the online and offline purchase was higher for tier I city customers than that of tier II city customers. The authors attributed this possibly because of the higher disposable income of the younger population living in tier I cities than that living in tier II cities (Balsara \& Singh, 2017). The education level and the technology acquittance could be on higher side in tier I cities of India. The other factors that could create this difference, would be high purchase density of millennials in the tier I cities, making the cost per delivery lower due to economies of scale, relative to tier-II or tierIII Indian cities. This difference could also be attributed to better infrastructure available in Indian tier-I cities. This shortened the delivery time in case of online purchase in tier I cities. There was no significant difference between the average ticket size of the purchase, with tier-I cities as compared to non-tier -I cities of India. This was because with the boom in e-commerce in India as well as the government push towards digitization in India (Nayak \& Bhattacharyya, 2019; Nayak Bhattacharyya \& Krishnamoorthy, 2019). Thus, one must note that for the mobile phone category, same product range was available for purchase throughout the country. Thus, the frequency of purchase differed among the different tier Indian cities, however the ticket size remained same. 
Table 8. ANOVA with location as an independent variable

\begin{tabular}{|c|c|c|c|c|c|c|}
\hline \multicolumn{2}{|c|}{} & $\begin{array}{c}\text { Sum of } \\
\text { Squares }\end{array}$ & df & Mean Square & F & Sig. \\
\hline \multirow{2}{*}{$\begin{array}{c}\text { frequency of online } \\
\text { shopping }\end{array}$} & Between Groups & 3.649 & 1 & 3.649 & 6.101 & .014 \\
\cline { 2 - 7 } & Within Groups & 157.889 & 264 & .598 & & \\
\cline { 2 - 7 } & Total & 161.538 & 265 & & & \\
\hline \multirow{2}{*}{$\begin{array}{c}\text { frequency of offline } \\
\text { shopping }\end{array}$} & Between Groups & 2.382 & 1 & 2.382 & 4.984 & .026 \\
\cline { 2 - 7 } & Within Groups & 126.163 & 264 & .478 & & \\
\cline { 2 - 7 } & Total & 128.545 & 265 & & & \\
\hline \multirow{2}{*}{\begin{tabular}{c} 
Avg ticket size \\
\cline { 2 - 7 }
\end{tabular}} & Between Groups & 3.481 & 1 & 3.481 & 1.761 & .186 \\
\cline { 2 - 7 } & Within Groups & 521.801 & 264 & 1.977 & & \\
\cline { 2 - 7 } & Total & 525.282 & 265 & & & \\
\hline \multirow{2}{*}{$\begin{array}{c}\text { Avg tickequency of purchase } x \\
\text { frize (D9 XD11) }\end{array}$} & Between Groups & 143.864 & 1 & 143.864 & 7.809 & .006 \\
\cline { 2 - 7 } & Within Groups & 4863.896 & 264 & 18.424 & & \\
\cline { 2 - 7 } & Total & 5007.759 & 265 & & & \\
\hline
\end{tabular}

The ANOVA result in Table 9 indicated that there was significant difference between engineering and non-engineering millennial customers when it involved regarding the frequency of online purchase and purchase exposure. Engineering education stream, millennial customers who had more technical knowledge had a higher frequency of online purchase than the other set of millennials (non-engineers) customer who had lesser technical expertise. This rationale supported the result could be that the nature of the former consumers was being more technology friendly and inquisitive in comparing the products which online platforms offered. So, such customer had more insights. However, this difference was meagre when it involved offline shopping of electronic purchase and the average ticket size of the purchase. This implied that in terms of gadget usage even non-engineering millennials

Table 9. ANOVA with education stream as an independent variable

\begin{tabular}{|c|c|c|c|c|c|c|}
\hline & & $\begin{array}{l}\text { Sum of } \\
\text { Squares }\end{array}$ & df & Mean Square & $\mathbf{F}$ & Sig. \\
\hline \multirow{3}{*}{$\begin{array}{l}\text { frequency of online } \\
\text { shopping }\end{array}$} & Between Groups & 4.292 & 1 & 4.292 & 7.207 & .008 \\
\hline & Within Groups & 157.245 & 264 & .596 & & \\
\hline & Total & 161.538 & 265 & & & \\
\hline \multirow{3}{*}{$\begin{array}{l}\text { frequency of offline } \\
\text { shopping }\end{array}$} & Between Groups & 1.551 & 1 & 1.551 & 3.225 & .074 \\
\hline & Within Groups & 126.994 & 264 & .481 & & \\
\hline & Total & 128.545 & 265 & & & \\
\hline \multirow[t]{3}{*}{ Avg ticket size } & Between Groups & .038 & 1 & .038 & .019 & .890 \\
\hline & Within Groups & 525.244 & 264 & 1.990 & & \\
\hline & Total & 525.282 & 265 & & & \\
\hline \multirow{3}{*}{$\begin{array}{c}\text { frequency of purchase } x \\
\text { Avg ticket size (D9 XD11) }\end{array}$} & Between Groups & 77.493 & 1 & 77.493 & 4.149 & .043 \\
\hline & Within Groups & 4930.267 & 264 & 18.675 & & \\
\hline & Total & 5007.759 & 265 & & & \\
\hline
\end{tabular}


Table 10. ANOVA with gender as an independent variable

\begin{tabular}{|c|c|c|c|c|c|c|}
\hline & & $\begin{array}{l}\text { Sum of } \\
\text { Squares }\end{array}$ & df & Mean Square & $\mathbf{F}$ & Sig. \\
\hline \multirow{3}{*}{$\begin{array}{l}\text { frequency of online } \\
\text { shopping }\end{array}$} & Between Groups & 11.047 & 1 & 11.047 & 19.346 & .000 \\
\hline & Within Groups & 150.176 & 263 & .571 & & \\
\hline & Total & 161.223 & 264 & & & \\
\hline \multirow{3}{*}{$\begin{array}{l}\text { frequency of offline } \\
\text { shopping }\end{array}$} & Between Groups & .985 & 1 & .985 & 2.032 & .155 \\
\hline & Within Groups & 127.453 & 263 & .485 & & \\
\hline & Total & 128.438 & 264 & & & \\
\hline \multirow[t]{3}{*}{ Avg ticket size } & Between Groups & .062 & 1 & .062 & .031 & .860 \\
\hline & Within Groups & 521.772 & 263 & 1.984 & & \\
\hline & Total & 521.834 & 264 & & & \\
\hline \multirow{3}{*}{$\begin{array}{l}\text { frequency of purchase } x \\
\text { Avg ticket size (D9 XD11) }\end{array}$} & Between Groups & 44.922 & 1 & 44.922 & 2.395 & .123 \\
\hline & Within Groups & 4933.584 & 263 & 18.759 & & \\
\hline & Total & 4978.506 & 264 & & & \\
\hline
\end{tabular}

were at par with their engineering peers. This held true both when it involved purchasing premium products or value for money products.

As per the ANOVA analysis result as depicted in Table 10, frequency of online shopping differed among the genders. It was evident that males tended to be more active buyer of electronic gadgets through online medium than their female counterparts. This was probably because females had a higher frequency of shopping online on other categories like fashion, health products and such others. Similar kind of result were found in other extant studies (Malar \&Thomson 2016), wherein significant relationship between gender and the positive product review was found. For reporting phase II (qualitative phase) results, the main findings from the qualitative interview of the respondents has been tabulated in Table 11.

\section{CONCLUSION}

The research was carried out by the authors to study the impact of OCR for young customers (millennials) in India. The authors first referred journals and articles published in the relevant field. They then listed a set of variables which could potentially be important and relevant affecting factors for millennials in decision making for purchase of mobile phones online. The study variables were operationalized through scale development. The proposed model was also presented at this stage. To carry out statistical analysis, the authors formulated fifteen hypotheses for the defined variables. The proposed hypotheses were tested on the data collected in the quantitative phase. Insights were drawn using statistical modelling. Subsequently, further, analysis was also carried out on the insights gathered in qualitative phase. Statistical modelling assisted in developing a model on OCRs regarding review sharing by establishing a relationship between the proposed factors. The authors analyzed the model to study the significant relationships between the mentioned factors. A better fit model was thus arrived at following the SEM analysis. In the most appropriate model developed, certain factors initially considered for the initial proposed model were the dropped subsequently. This resulted in an OCR model on review sharing and had three dependent variables. The developed model on OCR sharing, consisted of two independents (Web Platform Offering and Brand Loyalty), one dependent (review sharing) and two mediating variables (Purchase exposure and Frequency of online purchase). 


\begin{tabular}{|c|c|c|c|}
\hline $\begin{array}{l}\text { Factors considered while } \\
\text { purchasing a } \\
\text { mobile phone }\end{array}$ & $\begin{array}{l}\text { Influence of online } \\
\text { reviews on purchase }\end{array}$ & $\begin{array}{l}\text { Influence of friends \& } \\
\text { families on purchase }\end{array}$ & $\begin{array}{l}\text { Views regarding writing } \\
\text { online reviews }\end{array}$ \\
\hline $\begin{array}{l}\text { Respondents pointed out } \\
\text { that } 70-80 \% \text { of the phones } \\
\text { worked in a similar manner. } \\
\text { They mainly considered: } \\
\text { - Price range (value for } \\
\text { money or premium) was } \\
\text { considered. } \\
\text { - Brand if the price level } \\
\text { was same. } \\
\text { - Support to the } \\
\text { applications through } \\
\text { processor, camera, battery } \\
\text { life, storage were also } \\
\text { considered. } \\
\text { - Recommendations from } \\
\text { friends/family members } \\
\text { were also a relevant factor. }\end{array}$ & $\begin{array}{l}\text { Respondents had } \\
\text { knowledge regarding } \\
\text { mobile phones, but they } \\
\text { generally tended to read } \\
\text { online reviews too. } \\
\text { - They sought opinions } \\
\text { from others also in addition } \\
\text { to reviews. } \\
\text { - They checked for average } \\
\text { ratings of a phone review } \\
\text { online. } \\
\text { - They engaged in an } \\
\text { informed purchase decision } \\
\text { making. They would refrain } \\
\text { from buying a phone if it } \\
\text { had bad reviews. }\end{array}$ & $\begin{array}{l}\text { - Personal experiences of } \\
\text { friends and family members } \\
\text { about phones did matter. } \\
\text { - If a greater number of } \\
\text { friends used a phone, this } \\
\text { fact would motivate to buy } \\
\text { the same. } \\
\text { - Phones were often viewed } \\
\text { as a status symbol amongst } \\
\text { friends. }\end{array}$ & $\begin{array}{l}\text { Respondents } \\
\text { - indulged more in } \\
\text { reading rather writing } \\
\text { reviews online. } \\
\text { - mostly wrote reviews } \\
\text { out of emotional burst. } \\
\text { That is either if they were } \\
\text { delighted or if they had a } \\
\text { substandard experience. }\end{array}$ \\
\hline
\end{tabular}

The results established that there was significant difference in the levels of frequency of online shopping, offline shopping, average ticket size and purchase exposure for the three demographic variables. These were amongst the respondents living in Indian tier-I \& non-tier-1 cities, respondents' education stream being engineering or non-engineering, and gender being male or female. Tier-I and non-tier-I city millennial customers had significantly different level regarding the frequency of online or offline purchase and purchase exposure. Tier-I city customers had registered a higher frequency level for the purchase, however no significant difference was found between the average ticket size of the purchase for both the both the groups of millennials. The relationship between engineering and non-engineering students differed significantly for frequency of online purchase and purchase exposure according to the study results. The offline purchase frequency for the both set of customers didn't differ much. While the average ticket size remained same for both the categories. It was established through this research that males tended to be more active buyer of electronic items and gadgets than females through online medium.

\section{MANAGERIAL AND THEORETICAL IMPLICATIONS}

It was crucial for the managers to study the trends and behavior of the generation, Gen $\mathrm{Y}$ in India. This was because Gen Y had become a major influencer of most of the online purchases. Within the millennials, while the youngest members were still dependent on their parents, the older millennials have begun to enter the age of their peek spending. Millennials demonstrated a novel and different way of connecting with brands, channels and services. The organizational managers heeding to their preferences could bring them onboard as customers early. They could thus capture a significant portion of the millennial's wallet over a period of time. Companies needed to innovate its business models as well as redefine its purposes, values with time. This was because millennials heeded to importance regarding a firm, its' products, services as well as the ideologies. Instances have occurred in the past wherein, extreme views against organizations or their executives had resulted in millennial shunning the firm products offered. Managers needed to focus on web platform offering as established by the model and innovate constantly to attract and retain brand loyal customers throughout their product journey. Brand managers who would be able to maintain a constant engagement with young consumers 
would flourish. The growth of Fassos in India, which highly promoted its products through social media based on latest trends, was a apt example to this reasoning (Dasgupta, 2015). Also, the negative reviews as provided by customers should be treated by firm managers as constructive feedbacks. Further if managers acknowledged this, customers would feel involved in product or service development. This would in turn result in long customer association. So, firm marketing managers had to develop a market intelligence gathering system to capture customer feedback which could comprehend the mind of a millennial customers.

The first theoretical implication of this study was the development of scales on Peer Influence (PI), Social status (SS), Review Sharing (RS), Critical Analysis Before Purchase (CABP), Review Influence (RI), Critical Review Analysis (CRA) and Brand Loyalty(BL) as variables. A model on Online Customer Reviews (OCR) was developed. This model explained the relationship of variables with factors such as frequency of online-offline purchase, average ticket size and purchase exposure. Further, the effect of education background (engineering -non-engineering), location (residents of Indian tier I cities -tier II cities) and gender on the online purchasing behavior of the millennials was comparatively studied.

\section{SCOPE AND FUTURE DIRECTIONS}

Millennials, though accounted for only $25 \%$ of the total population but have already surpassed the population of their immediately preceding generation that is the baby boomers globally (Fry, 2018). India, the nation home to the highest number of millennials around the world has around 67 percent of total population as a working population (Talreja, Wahi, Ghosh, Marwah, \& Verma, 2018). This substantial base of talented and employable population would certainly drive Indian economy into the future. Additionally, enough human capital would be supplied to developed nations as well from India (Raina, 2016). Substantive research has been carried out for millennials in the developed nations like US and Europe. The same models and findings however couldn't be applied for Indian millennials (Nair \& Bhattacharyya, 2018). The ideas and opinions of gen Y (or the millennials) cannot be generalized across the globe. This was because the characteristics were dependent on lot of influencing factors. These are inculcated through experiences over time and highly dependent on location. The characteristics namely, economics, politics and culture varied significantly in context of Indian population as compared to developed nations like United States and Europe. Indian millennials were still in formative years, having relatively a lower economic maturity, having good academic credentials, strong technical know-how, were laborious and work oriented.

With the increasing advent of digital India consisting of 430 Million users today, (Jain, Sanghi, \& Bawankule, 2018), the smart phone usage in India with lower data prices and increased affordability had increased significantly. Millennials were being stereotyped as digital natives (Barton, Fromm, \& Egan, 2012). Technology in social media had become a natural and an integral part of their work and life. Millennials didn't blindly trust on company paid advertisements but are engaged in carrying out extensive research and peer discussions prior to their online purchase (Daniel Newman, 2015). They actively got involved in experimenting new gadgets, expressing their opinions and experiences. Their reviews influenced customers' purchase decisions who aren't even directly related to them. In context of Indian population, the mobile purchase has been extensively carried out by millennials for themselves as well as for their family members. Thus, this scope was very relevant to initiate a research for studying Indian millennial's behavior in particular. Mobile phone being their most favored and used gadget towards which Indian millennial spent most of his time and effort. The study embarked a journey to understand Indian millennials purchasing behavior for product like mobile phone and this could be extended in future. The research could be extended in future to study in details the differences portrayed by Gen X versus Gen Y. Further comparative studies could be undertaken between rural vs urban Indian millennial and between electronic gadgets other than mobile phones or other items like apparels. 


\section{REFERENCES}

Agarwal, M. (2014). Understanding the Connected Consumer, 1. Retrieved March 21, 2019, from iamwire.com: http://www.iamwire.com/2014/01/understanding-connected-consumer/24383

Alain, Y. L. C., Li, B., Ngai, E. W. T., Ch'ng, E., \& Lee, F. (2016). Predicting online product sales via online reviews, sentiments, and promotion strategies: A big data architecture and neural network approach. International Journal of Operations \& Production Management, 36(4), 358-383. doi:10.1108/IJOPM-03-2015-0151

Aragoncillo \& Orus. (2018). Impulse buying behaviour: an online-offline comparative and the impact of social media. Spanish Journal of Marketing, 22(1), 42-62. <ALIGNMENT.qj></ALIGNMENT>10.1108/SJME03-2018-007

Bhattacharyya, S. S. (2011). Web 2.0 and its effect on the strategic directions of business firms and the boundary of the firm. International Journal of Business Competition and Growth, 1(4), 346-358. doi:10.1504/ IJBCG.2011.038698

Bhattacharyya, S. S. (2012). Observations on the realities regarding corporate social responsibility from the emerging economy of India. International Journal of Indian Culture and Business Management, 5(2), 162-183. doi:10.1504/IJICBM.2012.045643

Bhattacharyya, S. S., Rangarajan, R., \& Vyas, K. G. (2012). Reflections on mapping chaos in the business organisational landscape. International Journal of Business Innovation and Research, 6(1), 76-116. doi:10.1504/ IJBIR.2012.044258

Brightlocal. (2018). Learn: Brightlocal.com. Retrieved March 2019, from Brightlocal.com: https://www. brightlocal.com/learn/local-consumer-review-survey/\#local-business-review-habits

Campo, K., \& Breugelmans, E. (2015). Buying groceries in brick and click stores: Category allocation decisions and the moderating effect of online buying experience. Journal of Interactive Marketing, 31, 63-78. doi:10.1016/j. intmar.2015.04.001

Cattell, R. B. (1978). The. scientific use of factor analysis. Plenum. doi:10.1007/978-1-4684-2262-7

Chakraborty, U., \& Bhat, S. (2018). Credibility of online reviews and its impact on brand image. Management Research Review, 41(1), 148-164. doi:10.1108/MRR-06-2017-0173

Clark, L. A., \& Watson, D. (1995). Constructing validity: Basic issues in objective scale development. Psychological Assessment, 7(3), 309-319. doi:10.1037/1040-3590.7.3.309

Court, E. a. (2009). The consumer journey. Retrieved March 21, 2019, from mckinsey.com: https://www.mckinsey. com/business-functions/marketing-and-sales/our-insights/the-consumer-decision-journey

Creswell, J. W., \& Clark, V. L. P. (2017). Designing and conducting mixed methods research. Sage publications.

Cronbach, L. J. (1951). Coefficient alpha and the internal structure of tests. Psychometrika, 16(3), 297-334. doi:10.1007/BF02310555

Cronbach, L. J., \& Meehl, P. E. (1955). Construct validity in psychological test. Psychological Bulletin, 52(4), 281-302. doi:10.1037/h0040957 PMID:13245896

David Court, D. E. (2009, June). The Consumer decision journey. Retrieved from Mckinzey Quarterly: https:// www.mckinsey.com/business-functions/marketing-and-sales/our-insights/the-consumer-decision-journey

Duan, W., Gu, B., \& Whinston, A. B. (2008). Do online reviews matter? An empirical investigation of panel data. Decision Support Systems, 45(4), 1007-1016. doi:10.1016/j.dss.2008.04.001

Gorsuch, R. L. (1983). Factor analysis (2nd ed.). Erlbaum.

Hernandez-Ortega, B. (2019). Not so positive, please!: Effects of online consumer reviews on evaluations during the decision-making process. Internet Research, 29(4), 606-637. Advance online publication. doi:10.1108/ INTR-07-2017-0257

Huang, Y., Wang, N., Zhang, H., \& Wang, J. (2018). A novel product recommendation model consolidating price, trust and online reviews. Kybernetes. Advance online publication. doi:10.1108/K-03-2018-0143 
Indian Economy News. (2019, February 12). Retrieved March 2019, from ibef.org: https://www.ibef.org/news/ indian-smartphone-market-expands-145-pc-in-2018-idc

Jain, N., Sanghi, K., \& Bawankule, N. (2018). Digital Consumer Spending in India. The Boston Consulting Group; Google. The Boston Consulting Group. Google.

Jensen, M. P., Keefe, F. J., Lefebvre, J. C., Romano, J. M., \& Turner, J. A. (2003). One-and two-item measures of pain beliefs and coping strategies. Pain, 104(3), 453-469. doi:10.1016/S0304-3959(03)00076-9 PMID:12927618

Jolliffe, I. T., \& Cadima, J. (2016). Principal component analysis: a review and recent developments. Philosophical Transactions. Series A, Mathematical, Physical, and Engineering Sciences, 374(2065), 20150202.

Jordan, E. (2018). Walkersands communications. Retrieved March 2019, from walkersands: https://www. walkersands.com/wp-content/uploads/2018/07/Walker-Sands_2018-Future-of-Retail-Report.pdf

Khullar, K. (2016, December 19). Tech2. Retrieved March 2019, from firstpost.com: https://www.firstpost.com/ tech/news-analysis/amazon-vs-flipkart-the-fight-for-oneplus-exclusivity-3694471.html

Kuan, H. H., \& Bock, G. W. (2007). Trust transference in brick and click retailers: An investigation of the beforeonline-visit phase. Information \& Management, 44(2), 175-187. doi:10.1016/j.im.2006.12.002

Lee, H.-H., \& Ma, Y. J. (2012). Consumer perceptions of online consumer product and service reviews: Focusing on information processing confidence and susceptibility to peer influence. Journal of Research in Interactive Marketing, 6(2), 110-132. doi:10.1108/17505931211265426

Lee, S., \& Choeh, J. Y. (2017). Exploring the determinants of and predicting the helpfulness of online user reviews using decision trees. Management Decision, 55(4), 681-700. doi:10.1108/MD-06-2016-0398

Likert, R. (1932). A technique for the measurement of attitudes. Archives de Psychologie, 22(140), 5-55.

Lin, C. A., \& Xu, X. (2017). Effectiveness of online consumer reviews: The influence of valence, reviewer ethnicity, social distance and source trustworthiness. Internet Research, 27(2), 362-380. doi:10.1108/IntR-012016-0017

MacCallum, R. C., Widaman, K. F., Zhang, S. \& Hong, S., (1999). Sample size in factor analysis. Psychological Methods, 1, 84-99.

Medallia. (2016). Medallia Institute. Retrieved March 2019, from Medallia Institute: http://go.medallia.com/ rs/669-VLQ-276/images/Medallia-Millennials-Your-Most-Powerful-Brand.pdf

Nair, A. K., \& Bhattacharyya, S. S. (2018). Is sustainability a motive to buy? An exploratory study in the context of mobile applications channel among young Indian consumers. Foresight.

Nayak, B., \& Bhattacharyya, S. S. (2019). Integrating digital wisdom and human capital. Journal for Quality and Participation, 41(4), 20-23.

Nayak, B., Bhattacharyya, S. S., \& Krishnamoorthy, B. (2019). Democratizing health insurance services; accelerating social inclusion through technology policy of health insurance firms. Business Strategy \& Development, 2(3), 242-252. doi:10.1002/bsd2.59

Newman, D. (2015, April 28). Research Shows Millennials Don't Respond To Ads. Retrieved from Forbes: https://www.forbes.com/sites/danielnewman/2015/04/28/research-shows-millennials-dont-respond-toads/\#38c540a55dcb

O'Reilly, K. A., MacMillan, A., Mumuni, A. G., \& Lancendorfer, K. M. (2018). Factors affecting consumers' online product review use. Qualitative Market Research, 21(3), 375-400. doi:10.1108/QMR-01-2016-0004

Raina, R. (2016, April 11). What's different about the Indian Millenial. Retrieved March 2019, from peoplematters. in: https://www.peoplematters.in/article/hr-ready/whats-different-about-the-indian-millennial-13231?utm _ source=peoplematters\&utm_medium=interstitial\&utm_campaign=learnings-of-the-day

Reuters. (2018, October 25). Smart Phones emerge as bright spot for Indian Manufacturing. Economic Times.

Smith, A. N. (2017, June 6). Technology. Retrieved March 2019, from Business.com: https://www.business. com/articles/tech-savvy-millennials-at-work/ 
Stanley, M. (2017, March 17). Research. Retrieved March 2019, from Morganstanley: https://www.morganstanley. com/ideas/india-millennials-makeover-disruption-growth

Statista. (2019). Technology and Telecommunications. Retrieved March 2019, from Statista.com: https://www. statista.com/statistics/274658/forecast-of-mobile-phone-users-in-india/

Stimac, B. (2014, April 17). Popular Stories. Retrieved March 2019, from Greenbot: https://www.greenbot.com/ article/2145163/oneplus-one-phone-will-be-invite-only-out-of-the-gate.html

Tabachnick, B. G., \& Fidell, L. S. (2013). Using Multivariate Statistics (3rd ed.). Pearson.

Talreja, A., Wahi, R., Ghosh, S., Marwah, D., \& Verma, B. (2018, February). Inconsumer Business. Retrieved March 2019, from Deloitte: https://rls.net.in/wp-content/uploads/2018/02/Trendsetting-Millenials_RAI-Deloitte. pdf

Toriello, M. (2019, January). Perspectives on Retail and Consumer goods. Retrieved March 2019, from Mckinsey and company: https://www.mckinsey.com/ /media/mckinsey/industries/retail/our\%20insights/fast\%20action\%20 in\%20fast\%20food\%20mcdonalds\%20cfo\%20on\%20why\%20the\%20company\%20is\%20growing\%20again/ perspectives-on-retail-and-consumer-goods-number-7-january-2019-vf.ashx

Ullrich, S., \& Brunner, C. B. (2015). Negative online consumer reviews: Effects of different responses. Journal of Product and Brand Management, 24(1), 66-77. doi:10.1108/JPBM-05-2014-0611

Uttam Chakraborty, S. B. (2017). Credibility of online reviews and its impact on brand image. Management Research Review, 41(1), 148-164. doi:10.1108/MRR-06-2017-0173

Verma, S., Chaurasia, S. S., \& Bhattacharyya, S. S. (2019). The effect of government regulations on continuance intention of in-store proximity mobile payment services. International Journal of Bank Marketing, 38(1), 34-62. doi:10.1108/IJBM-10-2018-0279

Verma, S., \& Sekhar Bhattacharyya, S. (2016). Micro-foundation strategies of IOT, BDA, Cloud Computing: Do they really matter in bottom of pyramid? Strategic Direction, 32(8), 36-38. doi:10.1108/SD-06-2015-0093

Wang, Q., Wang, L., Zhang, X., Mao, Y., \& Wang, P. (2017). The impact research of online reviews' sentiment polarity presentation on consumer purchase decision. Information Technology \& People, 30(3), 522-541. doi:10.1108/ITP-06-2014-0116

Wanous, J. P., Reichers, A. E., \& Hudy, M. J. (1997). Overall job satisfaction: How good are single-item measures? The Journal of Applied Psychology, 82(2), 247-252. doi:10.1037/0021-9010.82.2.247 PMID:9109282

Wicks, D. (2015, November 15). Role of Social Media Marketing in Business. Retrieved March 2019, from Social Media today: https://www.socialmediatoday.com/social-business/role-social-media-marketing-business

Zablocki, Makri, \& Houston. (2019). Emotions Within Online Reviews and their Influence on Product Attitudes in Austria, USA and Thailand. Journal of Interactive Marketing, 46(May), 20-39. doi:10.1016/j.intmar.2019.01.001

Zhang, K. Z. K., Xu, H., Zhao, S., \& Yu, Y. (2018). Online reviews and impulse buying behavior: The role of browsing and impulsiveness. Internet Research, 28(3), 522-543. doi:10.1108/IntR-12-2016-0377

Zhong, Q., Liang, S., Cui, L., Chan, H. K., \& Qiu, Y. (2018). Using online reviews to explore consumer purchasing behaviour in different cultural settings. Kybernetes. Advance online publication. doi:10.1108/K-03-2018-011 
International Journal of Asian Business and Information Management Volume 12 •Issue 2 • April-June 2021 